Research Article

\title{
Profile of Sexually Transmitted Infections (STIs) among Patients Attending Community Health Centre (CHC), Rangat
}

\author{
RK Halder', Pradeep B ${ }^{2}$
}

${ }^{1}$ Department of Dermatology, G.B. Pant Hospital, Port Blair, Andaman and Nicobar Islands, India. ${ }^{2}$ Associate Professor, Department of Dermatology, SMIMS, Gangtok, Sikkim, India. DOI: https://doi.org/10.24321/2319.9113.201905

I $\mathbf{N} \quad \mathbf{F} \mathbf{O}$

\section{Corresponding Author:}

Pradeep B, Department of Dermatology, SMIMS, Gangtok, Sikkim, India.

E-mail Id:

drprady85@gmail.com

Orcid Id:

https://orcid.org/0000-0002-6358-0490

How to cite this article:

Halder RK, Pradeep B. Profile of Sexually Transmitted Infections (STIs) among Patients Attending Community Health Centre ( $\mathrm{CHC})$, Rangat. J Integ Comm Health 2019; 8(1): 33-37.

Date of Submission: 2019-12-09

Date of Acceptance: 2020-02-22

\section{$\begin{array}{llllllll}\mathbf{A} & \mathbf{B} & \mathbf{S} & \mathbf{T} & \mathbf{R} & \mathbf{A} & \mathbf{C} & \mathbf{T}\end{array}$}

Background: The sexually transmitted infections are common communicable diseases spread through sexual contacts and caused by a broad range of pathogens, e. g., bacteria, chlamydia, virus, fungus, protozoa, ectoparasites, etc.

Methods: The study was conducted at Community Health Centre, Rangat, Middle Andaman. This was a cross sectional study involving all the patients attended $\mathrm{CHC}$, Rangat during the period from April, 2017 to October, 2019. The statistical data is expressed as numbers and percentages.

Result: 23 patients were diagnosed to have STIs during the study period. Herpes genitalis is the predominant STI diagnosed in 6 patients followed by condyloma acuminata, chancroid, molluscum, trichomonas vaginitis and bacterial vaginosis.

Conclusion: Thus, we performed this study to analyse the prevalence of sexually transmitted infection among patients attending CHC, Rangat. This study will be useful for planning and implementation of health care.

Keywords: Prevalence, STI, STIS, Rangat, Andaman

\section{Introduction}

The Sexually Transmitted Infections are common communicable diseases spread through sexual contacts and caused by a broad range of pathogens, e.g., bacteria, chlamydia, virus, fungus, protozoa, ectoparasites, etc. ${ }^{1}$ Bacterial STIs such as gonorrhoea, syphilis, chancroid, donovanosis and lymphogranuloma venereum can easily be cured with antimicrobial therapy. In contrast, viral STIs, such as those caused by HIV, Human Papilloma Virus (HPV) and Herpes Simplex Virus 2 (HSV-2), are chronic infections, characterised by prolonged viral shedding and opportunity for infecting a sexual partner; these cannot be cured by antiviral therapy. Prevention offers the best approach to managing STIs.

Though STIs are common in urban areas, the STIs spread into rural communities as well. ${ }^{2}$ These age long diseases have been recognised as major public health and reproductive health challenges worldwide. The impact of STIs on the scarce resources of most individuals, family and developing nations are enormous and often under estimated. ${ }^{3}$

Andaman and Nicobar Islands is a United Territory of Government of India situated in the Bay of Bengal about $1100 \mathrm{kms}$ away from mainland of India. North and Middle 
Andaman is one of the three districts of the Union Territory of Andaman and Nicobar Islands created on $18^{\text {th }}$ August, 2006 by bifurcating erstwhile Andaman district. Mayabunder is the district headquarters of the district. The total area of the district is 3251.85 sq. $\mathrm{kms}$. The climate is moist with moderate to heavy rainfall and very high relative humidity. The population of the district was 1, 05539 (Census-2011) and Sex ratio of 925 females for every 1000 males. Now the approximate population may be about 1,35000 . Majority of the population of the district is Bengali (>95\%). The Tamil, Malayali, Telegu and Ranchi community from Chhota Nagpur (Tribals: e.g., Munda, Dungdung, Kerketta, Kispotta, Ekka, etc) also live in the district.

The socio-economic condition of the people in North and Middle Andaman district is poor. Most of the people in the district are cultivators, labourers, fishermen, small traders; a few are group-D and $C$ government staff. The education facilities are available in the district; but quality of education is very poor. However, the literacy rate is about $86 \%$.

The society in A \& N Islands is usually without any sociocultural barrier and social restriction; mostly polygamous in nature, particularly the Penal Settlers in Port Blair and Nicobarese in Nicobar Islands. The penal settlers have lost their original cultural identity. But the islanders migrated after independence have definite cultural identity; however, they are influenced by the culture and the social behaviour of the Penal Settlers mostly settled in and around Port Blair. The five races of the Primitive Tribes, namely Shompens, Onges, Sentinalese, Jarawa and Great Andamanese, are strictly monogamous and have distinct cultural and linguistic identity. The capital Port Blair is the only town in the islands and is a combined defence base of army, navy and air forces.

Three major islands of Andaman group of Islands (South, Middle and North Andamans) are connected by Andaman Trunk Road. Port Blair is situated in South Andaman Island. Regular boat and helicopter services are also available. As a result, there is increased influence of urban society and tourists on the erstwhile isolated rural areas of North and Middle Andaman Islands.

A \& N Islands is a well - known tourist destination. There is no declared red-light area in Port Blair yet. But there are illegal brothels in some areas like Shadipur, Dugnabad, Dollygunj, etc. The girls and females of these brothels are mostly from poor families of outer islands. Many females in Port Blair work as call-girls or part-time sex worker.

The diseases in a community depend on various factors: geography, climate, socio-economic status, education status, nutrition, food habits, sexual behaviour, genetic and other habits of the community. In addition, poor hygiene, lack of basic amenities and overcrowding also play significant role in occurrence of diseases. Same is true in case of STIs.

\section{Aims and Objective}

To know and record the profile of the Sexually transmitted Diseases (STDs) in the rural areas of Andaman Islands amongst the patients attended $\mathrm{CHC}$, Rangat, Middle Andaman.

\section{Methods}

This was a cross sectional study involving all the patients attended CHC, Rangat during the period from April, 2017 to October, 2019. The study was conducted at Community Health Centre, Rangat, Middle Andaman by the only Venereologist of the UT administration. The patients with STIs who reported during the study period were included in the study. The patients who denied to participate in the study were excluded. Patients with STIs of all ages were included in this study. The samples from the patients were tested at the laboratory of the $\mathrm{CHC}$ where one laboratory Technician and two laboratory assistants were available. All cases of STIs were referred to the Venereologist for management.

The patients presented at Community Health Centre, Rangat, Middle Andaman with signs and symptoms of STIs and detected by laboratory investigations were included in the study.

Patient consent was obtained. Ethical committee clearance was obtained for performing this study.

\section{Specimen Collection and Testing}

The type of specimen collected was based on the clinical diagnosis at presentation. In patients with discharge, swabs were taken from urethra in male or endocervix in female. Smears made on glass slide for immediate observation under high power field (for Trichomoniasis) or stained.

\section{High Vaginal and Endocervical Swabs}

Separate swabs were then taken from the posterior fornix and endocervix with sterile swab sticks after adequate exposure using sterile bivalve speculum. The sample from the vagina was smeared on 2 separate glass-slides following which normal saline and potassium hydroxide was put on each of the slides respectively. Venous blood samples were also aseptically collected from the participants in sterile container for processing. HIV testing was unlinked, anonymous, therefore informed consent and counselling was not necessary.

\section{Processing of Samples}

All samples were processed by the same group of staff under the direct supervision of the author to ensure compliance to standard procedure and remove observer errors.

\section{Direct Examination}

Wet mount was performed on all swab samples using 
sterile normal saline for examination of typical yeast cells with hyphae or pseudo hyphae and Trichomonas vaginalis. Gram stain was performed and the slide was examined with $100 x$ objective under oil immersion for Gram negative diplococcic and clue cells.

\section{Identification of Isolates}

Gardnerella vaginalis (Bacterial vaginosis) was identified by a combination of wet preparation appearance, Gram staining reaction and the $\mathrm{pH}$ of the discharge. The wet mount preparation was examined for 'clue cells' (squamous epithelial cells whose surfaces were smothered with masses of micro-organisms), the $\mathrm{pH}$ of the saline preparation was found to vary between 5.0 to 5.6 (higher than normal $\mathrm{pH}$ of $3.0-4.5$ ) and in a Gram stain of positive cases.

\section{KOH Preparation}

Candida albicans were identified on basis of thick-walled oval yeast cells with pseudmycelium and Gram staining. Gram staining was done to identify other pathogens causing STIs (e.g. N. gonorrhoea).

\section{Serological Tests}

VDRL, Rapid Test for HIV $1+2$ and HBsAg were done for every patient presented with history and / or symptoms of STIs. All pregnant patients too were subjected to undergo these tests. ELISA for HIV was done when the reagent was available.

Clinical history and examinations were the main acumen for diagnosis of Herpese genitalis, Molluscum contagiosum, Genital warts (HPV), etc.

\section{Statistical analysis}

The statistical data is expressed as number and percentage.

\section{Result}

Total number of patients who attended at $\mathrm{CHC}$, Rangat during the period from $1^{\text {st }}$ May, 2017 to $30^{\text {th }}$ September, 2019 is 183307.

Total cases of STIs who attended at $\mathrm{CHC}$, Rangat during the period from $1^{\text {st }}$ May, 2017 to $30^{\text {th }}$ September, 2019 are 23.

Table I.Details of the patients

\begin{tabular}{|c|c|c|c|c|}
\hline S. No. & $\begin{array}{l}\text { The period of } \\
\text { study in months }\end{array}$ & $\begin{array}{c}\text { Total number of patients } \\
\text { who attended CHC, Rangat }\end{array}$ & $\begin{array}{l}\text { Total number } \\
\text { of STI patients }\end{array}$ & Diagnosis \\
\hline 1. & May, 2017 & 5484 & Nil & - \\
\hline 2. & June, 2017 & 5875 & 01 & Molluscum contagiosum \\
\hline 3. & July, 2017 & 6229 & 01 & Trichomonas vaginitis \\
\hline 4. & August, 2017 & 6449 & 01 & Chancroid \\
\hline 5. & September, 2017 & 6238 & 02 & $\begin{array}{l}\text { Trichomonas vaginitis - } 01 \\
\text { Herpes simplex genitalis - } 01\end{array}$ \\
\hline 6. & October, 2017 & 6230 & Nil & -- \\
\hline 7. & November, 2017 & 6328 & 01 & NSU \\
\hline 8. & December, 2017 & 6102 & 01 & Bacterial vaginosis \\
\hline 9. & January, 2018 & 5877 & 01 & Chancroid \\
\hline 10. & February, 2018 & 6879 & 01 & Herpes genitalis - 01 \\
\hline 11. & March, 2018 & 6599 & Nil & -- \\
\hline 12. & April, 2018 & 5370 & 01 & Trichomonas vaginitis \\
\hline 13. & May, 2018 & 5725 & 01 & Candidal vulvovaginitis \\
\hline 14. & June, 2018 & 5442 & Nil & \\
\hline 15. & July, 2018 & 6102 & 01 & Herpes genitalis \\
\hline 16. & August, 2018 & 6433 & Nil & - \\
\hline 17. & September, 2018 & 6719 & Nil & - \\
\hline 18. & October, 2018 & 7143 & 02 & $\begin{array}{c}\text { HIV-1 - } 01 \\
\text { Bacterial vaginosis }-01\end{array}$ \\
\hline 19. & November, 2018 & 6373 & 01 & Molluscum contagiosum \\
\hline 20. & December, 2018 & 6468 & 01 & Condyloma accunimata (HPV) \\
\hline 21. & January, 2019 & 6433 & 01 & Trichomonas vaginitis \\
\hline
\end{tabular}




\begin{tabular}{|c|c|c|c|c|}
\hline 22. & February, 2019 & 5820 & Nil & NSU \\
\hline 23. & March, 2019 & 5917 & 01 & - \\
\hline 24. & April, 2019 & 5636 & Nil & Herpes simplex genitalis \\
\hline 25. & May, 2019 & 5292 & 01 & -- \\
\hline 26. & June, 2019 & 5000 & Nil & Bacterial vaginosis \\
\hline 27. & July, 2019 & 6851 & 01 & Nil \\
\hline 28. & August, 2019 & 6306 & 02 & $\begin{array}{c}\text { Herpes simplex genitalis -01 } \\
\text { Condyloma accunimata- 01 }\end{array}$ \\
\hline 29. & September, 2019 & 5920 & 01 & Herpes simplex genitalis \\
\hline 30. & October, 2019 & $\mathbf{6 0 6 7}$ & $\mathbf{2 3}$ & \\
\hline Total & $\begin{array}{c}\mathbf{2} \text { years and 6 } \\
\text { months }\end{array}$ & $\mathbf{1 8 3 3 0 7}$ & & \\
\hline
\end{tabular}

Table 2.STIS with syndromic approach

\begin{tabular}{|c|c|c|c|}
\hline S. No. & STIs according to Syndromes & Aetiological diagnosis & Total Number of STIs \\
\hline 1. & Genital Ulcer syndrome & H. genitalis & 06 \\
\hline & - do- & Condyloma accunimata (HPV) & 02 \\
\hline & - do- & Chancroid & 02 \\
\hline & - do- & Molluscum contagiosum & 02 \\
\hline & - do- & Non-specific urithitis & 03 \\
\hline 6. & Genital discharge syndrome & Trichomonas vaginitis & 05 \\
\hline & -Do- & Bacterial vaginosis & 03 \\
\hline Total & & & $\mathbf{2 3}$ \\
\hline
\end{tabular}

Table 3.Age and sex distribution of the patients

\begin{tabular}{|c|c|c|c|c|c|}
\hline \multirow{2}{*}{ S. No. } & \multirow{2}{*}{ Age of the patients } & \multirow{2}{*}{$\begin{array}{l}\text { No. of } \\
\text { patients }\end{array}$} & \multicolumn{2}{|c|}{ Sex of the patients } & \multirow{2}{*}{ STIs with number of STIs each } \\
\hline & & & Male & Female & \\
\hline 1. & Below 15 years & 01 & 01 & -- & Chancroid \\
\hline 2. & 15 years to 19 years & 03 & 02 & 01 & $\begin{array}{l}\text { Herpes simplex genitalis - } 02 \\
\text { Candidal vulvovaginitis - } 01\end{array}$ \\
\hline 3. & 20 years to 29 years & 10 & 05 & 05 & $\begin{array}{c}\text { H. genitalis - } 02 \\
\text { Condyloma accunimata-02 } \\
\text { Trichomonas vaginitis-03 } \\
\text { Non-specific urethritis -- } 02 \\
\text { HIV - } 01 \\
\end{array}$ \\
\hline 4. & 30 years to 39 years & 06 & 02 & 04 & $\begin{array}{l}\text { Trichomonas vaginitis }-02 \\
\text { Molluscum contagiosum -01 } \\
\text { Bacterial vaginosis }-02 \\
\text { Non-specific urethritis } 01\end{array}$ \\
\hline 5. & 40 years to 49 years & 03 & 03 & --- & $\begin{array}{c}\text { H. genitalis }-02 \\
\text { Molluscum contagiosum - } 01\end{array}$ \\
\hline Total & & 23 & 13 & 10 & \\
\hline
\end{tabular}

The details regarding the STI patients (Table 1 ), the syndromic diagnosis (Table 2) and the age wise distribution (Table 3 ) are mentioned as follows.
No patient was found suffering from Syphilis and HBsAg.

\section{Discussion}

STIs accounts to the causation of several cases of acute 
illness, infertility, long-term disability and death, with serious medical and psychological consequences to millions of men, women and infants globally. ${ }^{4,5}$ Since sexual behavior and practice is private, intimate and sensitive, respondents may feel mortified or ashamed to report syndromes. ${ }^{6}$ STI prevalence in any society is directly related to the extent of awareness, level of education, socio-economic status, appropriate diagnosis and rational medication, and importantly the policy making and implementation ${ }^{7}$

The incidence of Sexually Transmitted Infections is low in the rural areas of Andaman Islands. There were 23 cases of STIs amongst 183307 patients who attended the Community Health Centre over a period of two years six months. However, the incident of patients with Vaginal Discharge Syndrome with lower abdominal pain was 115. High incidence of PID could be due to poor hygiene and anaemia of the rural females in North and Middle Andaman Islands. There were 03 cases of bacterial vaginosis and 05 cases of Trichomonas vaginalis out of 115 cases of PID. There was no case of Gonorrhoea, Chlamydia, Syphilis, Donovanosis and Hepatitis-B (HBsAg). This could be due to limitations of investigations in the rural area. There was no facility of Culture and Sensitivity Test. Availability of PCR and Dark Ground Microscope could diagnose more cases of STIs.

Andaman Islands were still remote and isolated area. The islanders were yet to be exposed to urban culture in mainland of India. Therefore, the incidence of STIs were found to be very low. Moreover, better Primary Health Care facility and awareness could be other contributory factors of low incidence of STIs in North and Middle Andaman Islands.

This was the maiden study done on the profile of STIs in the rural areas of Andaman group of Islands. The prevalence rate of STIs among students of tertiary educational institutions of $70.60 \%$ was higher than the prevalence rate presented by the national (Nigeria) survey on STIs, Basuaye in Benin and Aboyeji in Ilorin whose overall prevalence rate was $11.50 \%$, $11.8 \%$ and $49.4 \%$ respectively. The difference could be due to the methodology employed in the national survey which included all category of the population including students. This high rate might also be due to narrowing the study population to students which make up the largest group of youth who are sexually active and adventurous. ${ }^{8}$

\section{Conclusion}

Thus, we performed this study to analyse the prevalence of sexually transmitted infection among patients attending CHC, Rangat (Middle Andaman) which has not been published yet. The incidence of STIs is low in this part of our country because of the good moral, cultural and ethical values of the people. But the stringent surveillance and preventive measures are to be followed to eradicate the STIs here.

\section{Conflict of Interest: None}

\section{References}

1. Write RG, Orroth KK, Glynn JR, Freeman EE, Habbema $J D$, Terris-Prestholt $F$ et al. Treating curable sexually transmitted infections to prevent HIV in Africa: still an effective control strategy? J Acquir Immune Defic Syndr 2008; 47(3): 346-353. Available from: https:// europepmc.org/article/pmc/pmc3776949 [PubMed/ Google Scholar].

2. Hayes RJ, Jones DW, Celum C, et al. Treatment of sexually transmitted infections for HIV prevention: End of the road or new beginning? AIDS 2010; 24(04): S15-26. Available from: https://insights.ovid.com/ pubmed?pmid=21042049 [PubMed/ Google Scholar].

3. Holmes KK, Levine R, Weaver M. Effectiveness of condoms in preventing sexual transmitted infections. Bulletin of the World Health Organization 2004; 82(6): 454-461. [PubMed/ Google Scholar].

4. Meade JC, Cornelius DC. Sexually transmitted infections in the tropics. Curr Top Trop Med 2012: 457. [ResearchGate/ Google Scholar].

5. Torrone EA, Morrison CS, Chen PL, Kwok C, Francis SC, Hayes RJ et al. Prevalence of sexually transmitted infections and bacterial vaginosis among women in sub-Saharan Africa: An individual participant data metaanalysis of 18 HIV prevention studies. PLoS medicine 2018; 15(2): e1002511. Available from: https://journals. plos.org/plosmedicine/article?id=10.1371/journal. pmed.1002511 [Google Scholar].

6. Kassie BA, Yenus H, Berhe R, Kassahun EA. Prevalence of sexually transmitted infections and associated factors among the University of Gondar students, Northwest Ethiopia: a cross-sectional study. Reproductive health 2019; 16(1): 163. [PubMed/ Google Scholar].

7. Thapar R, Riyaz M, Kaur N. Prevalence and Pattern of Sexually Transmitted Diseases in a Tertiary Care Hospital in Chamba, Himachal Pradesh. Journal of Contemporary Medical Research 2018; 5(5): E5-9. Available from: https://www.ijcmr.com/uploads/7/7/4/6/77464738/ ijcmr_2025_v1.pdf [Google Scholar].

8. Thairu Y, Shehu HA, Egenti N. Profile of Sexually transmitted infections (STIS) among students of tertiary educational institution in Abuja, Nigeria. Journal of Dental and Medical Sciences 2015; 14(11): 71-74. [ResearchGate/ Google Scholar]. 